\title{
Joanna Rokita-Jaśkow/ Werona Król-Gierat (red.), Wczesny start jezykowy, wybrane zagadnienia. Wydawnictwo Naukowe Uniwersy- tetu Pedagogicznego, Kraków 2017, 202 s.
}

Monografia pod redakcją Joanny Rokity-Jaśkow oraz Werony Król-Gierat pt. Wczesny start językowy, wybrane zagadnienia to pokłosie międzynarodowej konferencji naukowej Child Foreign Language Learning. Between Theory and Practice (Nauczanie języków obcych dzieci. Między teoria a praktyka), która odbyła się w dniach 2830 kwietnia 2016 roku w Krakowie. Temat zarówno konferencji, jak i publikacji, bardzo dobrze wpisuje się w obecną politykę językową w Polsce - elementy obligatoryjnej nauki języka obcego obowiązują wszystkie sześciolatki (zob. Rozporządzenie MEN z dnia 14 lutego 2017 roku Dz.U. z 2017 r., poz. 365). Istotne są zatem wszystkie kwestie związane z procesem glottodydaktycznym na etapie przed- i wczesnoszkolnym, a więc metody nauczania języka obcego, ewaluacja sprawności językowych, materiały dydaktyczne czy kompetencje, jakimi powinni się legitymować nauczyciele uczący języka obcego na tych etapach edukacyjnych. Tematyka książki stanowi w pewnym stopniu kontynuację prac badawczych redaktorek, np. monografii Joanny Rokity-Jaśkow pt. Foreign language learning at pre-primary level: parental aspirations and educational practice (Nauczanie języka obcego na poziome przedszkolnym: aspiracje rodziców a praktyka edukacyjna), czy monografii Werony Król-Gierat pt. Teaching English as a Foreign Language in Inclusive Classrooms at the Lower-Primary Level. An Analysis of Teachers' Needs and the Achievements of Learners with Special Educational Needs (Nauczanie języka angielskiego jako obcego w oddziałach integracyjnych na etapie wczesnoszkolnym. Diagnoza potrzeb nauczycieli i osiagnięć uczniów ze specjalnymi potrzebami edukacyjnymi).

Recenzowana pozycja składa się z przedmowy, notek biograficznych oraz jedenastu artykułów, które zostały podzielone na trzy części tematyczne. Pierwsza część nosi tytuł: Cele nauczania dzieci języków obcych i drugich: aspekty teoretyczne, druga: Metody nauczania języków obcych $w$ klasie $i w$ środowisku domowym, natomiast trzecia: Przyswajanie języka drugiego w środowisku naturalnym/ dwujęzyczność. Studiując wymienione tytuły zakresów tematycznych można zauważyć, że w monografii przedstawia się wczesne rozpoczęcie nauki języka obcego/ drugiego z bardzo wielu różnych perspektyw. Ponadto podział treści na trzy części tematyczne sprawia wrażenie przejrzystości, zachęcając czytelnika do lektury.

W pierwszej części monografii umieszczono dwa artykuły. Pierwszy z nich to przyczynek Joanny Rokity-Jaśkow (s. 15-26), w którym badaczka podejmuje kwestię wczesnego startu językowego z perspektywy diachronicznej. Autorka omawia zmieniające się na przestrzeni ostatnich pięćdziesięciu lat cele i oczekiwania dotyczące osiągnięć językowych dziecka w zakresie nauki języka obcego oraz analizuje rozwój 
badań naukowych w tym obszarze. Prezentuje także teorie, za pomocą których tłumaczy się procesy zachodzące w klasie małego dziecka oraz poza nią, a także czynniki, które mają wpływ na osiągnięcia dzieci w nauce języka obcego. Kolejnym artykułem w tej części książki jest przyczynek Anny Schmidt (s. 27-46), która porusza kwestie związane z przedszkolnym nauczaniem języka angielskiego. Autorka podkreśla wagę wczesnego startu językowego, dokonuje charakterystyki przedszkolaka jako ucznia języka obcego, przedstawia kompetencje, jakimi powinni legitymować się nauczyciele języków obcych na etapie przedszkolnym oraz podkreśla istotę ewaluacji sprawności językowych na tym poziomie edukacyjnym. Oprócz powyższych rozważań badaczka prezentuje również praktyczne rozwiązania, a mianowicie techniki i formy pracy, które mogą być wykorzystane w nauczaniu języka obcego dzieci przedszkolnych.

Drugą część tomu otwiera artykuł Iwony Wowro (s. 47-70), w którym autorka podejmuje zagadnienie stosowania metody narracyjnej w nauczaniu języków obcych na wczesnym etapie edukacyjnym. Badaczka przedstawia specyfikę metody narracyjnej w nauczaniu języków obcych oraz prezentuje zarys i wyniki badania empirycznego, w którym analizowano efektywność stosowania tej metody w nauczaniu języka niemieckiego na etapie przed- $\mathrm{i}$ wczesnoszkolnym. Temat stosowania $\mathrm{w}$ nauczaniu języka obcego metody narracyjnej podejmuje także Mariusz Jakosz (s. 71-87) i omawia szczegółowo kompetencje oraz umiejętności, jakimi powinni legitymować się nauczyciele przedszkolni i wczesnoszkolni, stosujący w nauczaniu tę metodę. Z kolei Maria Stec (s. 88-105) skupia uwagę na materiałach glottodydaktycznych, które mogą wspierać rodziców we wczesnoszkolnym nauczaniu języków obcych ich dzieci. Autorka na podstawie przeglądu literatury fachowej oraz na podstawie badań ankietowych charakteryzuje materiały edukacyjne, które mogą być stosowane przez rodziców dzieci uczących się języka angielskiego w wieku przedszkolnym.

W tej części tomu znajdziemy również artykuł Magdaleny Woś (s. 106-122), w którym Autorka przedstawia cele nauki języka obcego dzieci w wieku przedszkolnym, wyjaśnia pojęcie edutainment w dydaktyce języka obcego, prezentuje metody aktywizujące w edukacji językowej przedszkolaków, kończąc artykuł przykładami gier i zabaw domowych, wspierających proces opanowania języka obcego u dziecka w wieku przedszkolnym.

Na końcu drugiej części monografii umieszczono przyczynek Katarzyny Nosidlak (s. 123-138), który dotyczy kształtowania kompetencji interkulturowej wśród przedszkolaków. Badaczka definiuje pojęcie kompetencji interkulturowej i ukazuje rolę tej kompetencji w procesie nauczania języka obcego. Poza tym autorka prezentuje sposób wstępnej oceny elementów kompetencji interkulturowej wśród przedszkolaków oraz przedstawia wnioski z przeprowadzonej przez nią interkulturowej pogadanki z dziećmi pięcio- i sześcioletnimi.

Trzecią część tomu rozpoczyna artykuł Anny Włoch (s. 139-153), w którym autorka zarysowuje politykę edukacyjną w zakresie nauczania języków obcych w wybranych państwach europejskich oraz na podstawie własnych badań porównuje ją z doświadczeniami rodziców, których dzieci uczęszczają do przedszkoli i szkół w wybranych krajach Unii Europejskiej. W kolejnym przyczynku Małgorzata Rocławska- 
Daniluk i Ewa Kowalewska (s. 154-173) pokazują, jak ważne jest wspieranie procesu glottodydaktycznego przez logopedę. Autorki analizując studium przypadku chłopca z ubytkiem słuchu wskazują na istotę czynników wpływających na edukację bilingwalną dzieci, do których zaliczają m.in. poprawną mowę w różnych językach. Do tematyki tego artykułu nawiązują również Barbara Kryc i Anna Mikulska (s. 174187), pokazując na podstawie studium przypadku dwujęzycznej dziewczynki ze specjalnymi potrzebami edukacyjnymi, jak istotne jest stosowanie wybranych metod logopedycznych $\mathrm{w}$ pracy $\mathrm{z}$ dziećmi dwujęzycznymi z zaburzeniami mowy w przedszkolu.

Ostatnim artykułem w tej części tomu jest przyczynek Jerzego Kowalewskiego (s. 188-202), w którym autor porusza kwestię nauczania języka polskiego jako obcego dzieci na Ukrainie. Badacz opisuje status języka polskiego w szkolnictwie ukraińskim, analizuje podręczniki do nauczania dzieci i młodzieży języka polskiego na Ukrainie, usiłując odpowiedzieć na pytanie, dlaczego zakładaną w nich kompetencję komunikacyjną nie zawsze można przełożyć na pożądane efekty.

Reasumując należy stwierdzić, że monografia pod redakcją Joanny Rokity-Jaśkow oraz Werony Król-Gierat Wczesny start językowy, wybrane zagadnienia to pozycja bardzo cenna oraz pożądana na rynku wydawniczym. Jest ona skierowana do szerokiego grona odbiorców: nauczycieli przedszkolnych oraz wczesnoszkolnych, zajmujących się nauczaniem języków obcych, studentów specjalizacji nauczycielskich na kierunkach neofilologicznych, badaczy procesów przyswajania języka obcego/ drugiego, a także rodziców, których dzieci uczą się języka obcego lub którzy wychowują swoje dzieci dwujęzycznie.

\section{Bibliografia}

Król-Gierat, W. (2017), Teaching English as a Foreign Language in Inclusive Classrooms at the Lower-Primary Level. An Analysis of Teachers' Needs and the Achievements of Learners with Special Educational Needs. Nieopublikowana rozprawa doktorska.

Rokita-Jaśkow, J./ W. Król-Gierat (2017) (red.), Wczesny start językowy, wybrane zagadnienia. Kraków.

Rokita-Jaśkow, J. (2013), Foreign language learning at pre-primary level: parental aspirations and educational practice. Kraków.

Rozporządzenie MEN z dn. 14 lutego 2017 roku [Dz.U. z 2017r., poz. 356]. (URL http://dziennikustaw.gov.pl/du/2017/356/1). [Pobrano 25.05.2018].

\section{Katarzyna SOWA-BACIA}

Uniwersytet Pedagogiczny im. Komisji Edukacji Narodowej w Krakowie/ Pedagogical University of Cracow

E-mail: katarzyna.sowa-bacia@up.krakow.pl, 